\title{
Problem-based learning opportunities within Ontario (Canada) elementary health and physical education
}

\author{
Thomas G. Ryan \\ Nipissing University, Ontario, Canada \\ Correspondence should be addressed to Thomas G. Ryan (iDｔhomasr@nipissingu.ca \\ Received 14 January 2021; Revised 20 June 2021; Accepted 24 June 2021
}

\begin{abstract}
The following content analysis unfolded while exploring the current Ontario provincial government positions detailed in the newly released 2019 Ontario Health and Physical Education curricular document. This newly released document informs and guides elementary educators towards a problem-based learning pedagogy. Problem-based learning opportunities within Ontario (Canada) Health and Physical Education places emphasis on the 'learning by doing' philosophy which increases learner awareness. The educator cognitively coaches, posing questions that lead the inquirer and the educational inquiry authentically while encouraging self-direction. PBL invites constructivism as self-directed students are confronted by carefully crafted authentic problems within Ontario Health and Physical Education.
\end{abstract}

Keywords: Health and physical education, problem-based learning, curriculum, pedagogy

\section{Introduction}

Problem-based learning (PBL) has authentic roots in Ontario (Canada) (Barrows \& Tamblyn, 1976, 1980), and is currently a favoured instructional mode in medical and health education globally (Norman \& Schmidt, 1992). PBL is a positive instructional mode that yields better long-term retention, greater skill development, and increased satisfaction of students and teachers compared to traditional modes of teaching and learning (Korpi et al., 2019). A “. . primary goal of PBL is to enhance students' application of knowledge, problem solving and self-directed learning skill by requiring them to actively articulate, understand and solve problems" (Jonassen \& Hung, 2008, p. 15). Acknowledging these traits within PBL led Hmelo-Silver (2004) to conclude that PBL is quite simply an "instructional method in which students learn through facilitated problem solving" ( $p$. 235). PBL is relatively popular today and it is widely accepted by many education stakeholders that teaching is more than content delivery (Lattuca, 2006), education is a process that is experienced by learners (Dewey, 1897).

Indeed, current teaching modes frequently include engagement planning, open-ended structuring and implementation that connects learning experiences to past student experience in such a manner as to accelerate learning while being grounded in collaborative and contextual elements of learning (Yew \& Goh, 2016). Learning by doing increases awareness within the learner and the educator becomes a cognitive coach posing carefully crafted questions that may lead the inquiry authentically, yet encourage self-direction (Lu \& Chan, 2015; Rasi \& Poikela, 2016). The teacher acts as coach and "coaches often offer advice, guidance, and inspiration, [and] ultimately watch the results of their efforts from the sidelines" (Hubbard, 2012, p. 160). Being a guide on the sidelines is a modern teacher position in classrooms; quite a change from the traditional teacher centred instructional stances. As new and innovative research makes claims while publishing outcomes, education takes note and moves forward. These research-based findings are both useful and needed since past research has demonstrated that the number of students enrolled in Health and Physical Education classes is definitely trending down within North America (Faulkner et al., 2007; Johnston et al., 2007). By changing curricula and instructional modes it is hoped that the enrollment decline can be reversed in schools. Figure one lays out a simplified comparative to PBL. 
Figure 1

Transition from traditional teaching mode to PBL mode

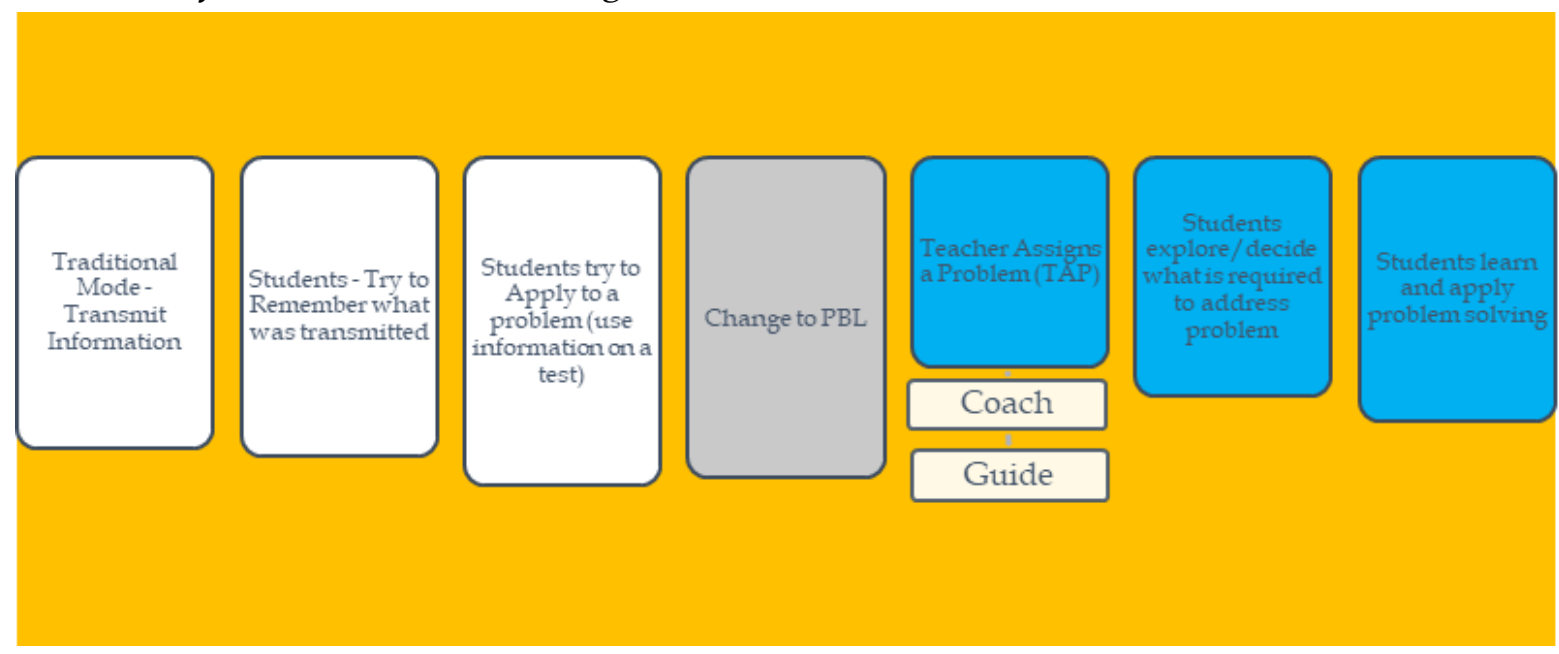

\section{Method}

This qualitative content analysis (Elo et al., 2014; Hsieh \& Shannon, 2018) involved "a systematic, replicable technique for compressing many words of text into fewer content categories (headings) based on explicit rules ..." (Stemler, 2001, p. 1). Herein, key terms emerged that became subheadings and only selective research within the last decade was prioritized. Close reading (Schreier, 2012) is the core element of iterative content analysis ". . . in order to understand what they meant to people, what they enable or prevent, and what the information conveyed by them does" (Krippendorff, 2004, p. xviii). All texts were revisited to reduce, reinterpret and reshape textual interpretations (Schreier, 2012), to develop qualitative insights, and link these to other elements in much the same way as a mind-map (Schreier, 2012). Content analysis is "a research method for the subjective interpretation of the content of text data" (Hsieh \& Shannon, 2005). Content analysis is highly descriptive recounting and summarizing texts to uncover fresh perspectives (Schreier, 2012) while grounding evidence. Current research findings were melded with a curricular guide, in this case the Ontario Health \& Physical Education (2019) document, which was recently enriched and implemented in Ontario, Canada.

\section{PBL}

Health and Physical Education involves learning yet what is learning? Learning is not an event, it is a process (Kolb \& Kolb, 2005) and once students are engaged in this process students need feedback to guide and support their efforts to learn. Hattie and Timperley (2007) believe, if "feedback is directed at the right level, it can assist students to comprehend, engage, or develop effective strategies to process the information intended to be learned" (p.104). The feedback is added to student identity and in a constructivist manner it is situated within experience and can be quite motivational. However, to be "effective, feedback needs to be clear, purposeful, meaningful, and compatible with students' prior knowledge and to provide logical connections" (p.104). Dewey (1897) claimed, "education must be conceived as a continuing reconstruction of experience: ... the process and goal of education are one and the same thing" (p.79). Hence the need to carefully engage within the process and coach students via effective feedback is understood and commonplace in education today as students move through the process of education while at the same time gathering experience. The learning process is filled with meaningful problems and dilemmas; problems can be solved however, dilemmas cannot, they require coping strategies.

As noted earlier, problem-based learning evolved from within the medical profession within the last fifty years while drawing on and entangled with many other learning theory modes such as, "Donald Schön's "reflective practitioner", John Dewey's "learning by doing", David Kolb's learning circle, Piaget's cognitive development theory, Krashen's input hypothesis, and Vygotsky's 
concept of the Zone of Proximal Development and scaffolding" (Pagander \& Read, 2014, p.7). Scaffolds can take many forms and are instructional designs within PBL that instigate student led inquiry while promoting conceptual integration, and reflection that can lead to a reduction in misconceptions (Simons \& Ertmer, 2005).

Mixing and borrowing the best attributes from each learning theory, concept and model, PBL has become an opportunity for students and teachers to reflect upon (Schon, 1983) authentic problems (Dewey, 1897) in the classroom. These carefully developed and staged problems are then explored recursively (Kolb \& Kolb, 2005) to realize solutions. This staged process involves cognitive and affective modes as well as physical action that is largely self-directed, as if to play with problems (Piaget, 1990). PBL can complement and blend with other pedagogical modes freeing the educator to move in and out of PBL while coaching, guiding and supporting students.

Engaging students via authentic problems seems to stimulate and motivate students (Barrows, \& Kelson, 1995; Scholkmann \& Roters, 2009). This empowerment triggers student leadership within group work and combined with self-evaluation enhances the learning. PBL can increase higher order thinking skills (HOTS) via timely questions which prompt the student to reflect deeply while considering justification for any answer put forward (Tarmizi \& Bayat, 2012). Recently, researchers Demirel and Dağyar (2016) completed a meta-analysis of close to 50 PBL investigations and determined PBL did positively impact student attitudes which is quite important in the learning process, as students are more likely to be engaged when they have a positive attitude towards the instructional mode. This positivity was also detected by Jin and Bridges (2014) who looked at many PBL studies however other researchers have noted there is a great deal of variety within the PBL deployment in classrooms which makes conclusions tenuous (Jerzembek \& Murphy, 2013).

\section{PBL and Constructivism}

Problem-based learning (PBL) is frequently linked to constructivism which can, and often is selfdirected, open-ended, and much more meaningful than traditional modes of instruction (Siminica \& Traistaru, 2013). The "constructivist view of learning position is that an active, self-regulated, goal-directed, and reflective learner constructs personal knowledge through discovery and exploration in a responsive learning environment" (Tennyson, 2010, p. 7). PBL is a studentcentered teaching mode with content and process steps that cultivate critical thinking and problem-solving skills (Flint, 2007; Savery, 2006). Constructivism involves learning by applying oneself actively in meaningful endeavours (Wilson, 2010), recursively and some researchers have claimed PBL is "one of the best exemplars of the constructivist learning environment" (Savery \& Duffy,1995, p. 135).

In PBL information is shared (supplied), engaging and moving students to brainstorm (discover) solutions, theory and possibilities (Olsen, 2014). The process is social, negotiated and collaborative (Vygotsky, 1934), unfolding in classrooms and gymnasiums. The teacher guides, offering support and structuring the task in a student-centred manner (scaffolding) as objectives are formed while working in small groups (squads). Self-study (reflection) may follow as information is gathered to produce new knowledge leading to clarity. Some may see these steps as stages within a PBL model as is the case with researchers (Lu \& Chan, 2015; Poikela \& Poikela, 2006). Regardless of the model, "PBL has been found to be superior when it comes to longterm retention, skill development, and satisfaction of students and teachers" (Korpi et al., 2019, p. 2).

Previously, Torp and Sage (2002) have suggested PBL involves, "defining problems, gathering information, analyzing data, building and testing hypotheses, comparing strategies with those other students and mentors, and sharing methods and conclusions" (p. 3). The teacher is cast in the role of facilitator and coach, who offers both verbal and nonverbal messages as higher order thoughts surface within squads (small groups often organized in the physical education classes). The squad members work together to achieve certain goals and in some cased the term coconstruction is appropriate via active dialogue, which is necessary in PBL, and intrinsic motivation grows as the pursuit of a learning grips the students (Gagné, 2010; Hmelo-Silver \& Barrows, 2015). 
To achieve certain outcomes in squads, squad members need to co-operate with one-another, which is again another model (co-operation) used in current Health and Physical education programs.

Figure 2

Levels and sectors of the new way of learning - PBL (Korpi et al., 2019)

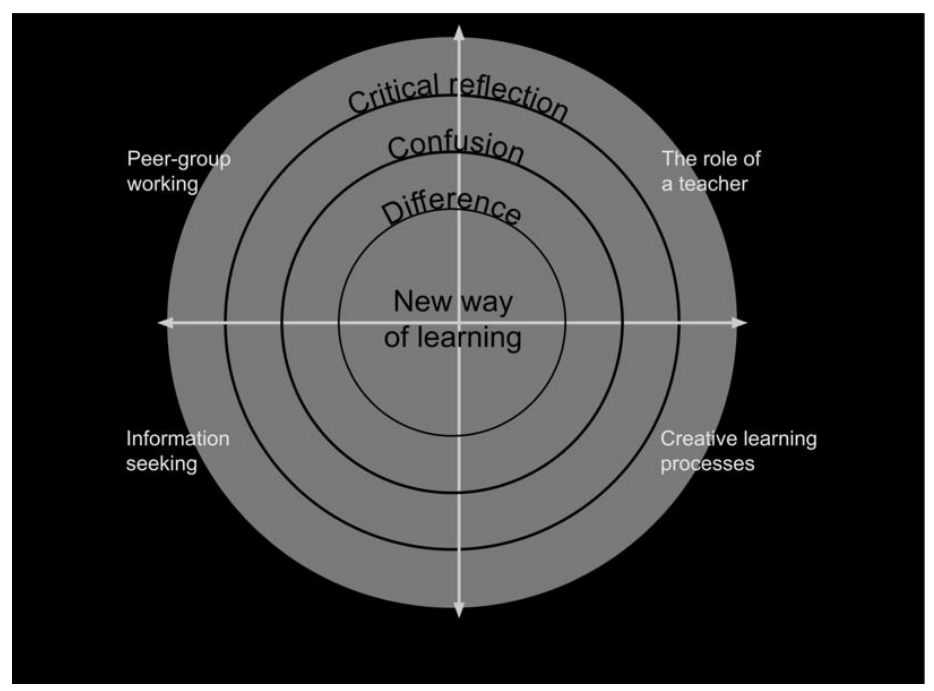

\section{PBL and Authenticity}

The educational philosopher Dewey proposed that the school must represent real life (Archambault, 1964), in order to engage and motivate students to connect with the larger community in which the school was situated. By choosing a PBL teaching approach educators provide students with complex open-ended real-world problems to solve in a self-directed learning environment, positioning the educator in the role of facilitator, who is responsible for guiding students as required (McCaughan, 2015). This is not the first time this advice has been offered, many years ago researchers were suggesting; "students are more likely to become engaged with authentic academic work that intellectually involves them in a process of meaningful inquiry to solve real life problems that extend beyond the classroom" (Shernoff et al., 2003, p. 159). PBL is also a process (Kolb \& Kolb, 2008), that is often a collaborative group task infused with reflective practices. Teachers need to embrace PBL, and to do this may require pedagogical change and admission that PBL does engage, motivate and address authentic issues in society.

\section{PBL as Pedagogy}

Pedagogy has been defined as the "interactions between teachers, students, and the learning environment and the learning tasks" (Murphy, 2008, p. 35). When students are at the core of this interactional process this mode of pedagogy has been labelled learner-centered pedagogy which includes constructivism that is both participatory and actively hands-on. The teacher facilitates this process, but also creates and structures the conditions for learning by carefully crafting problems that challenge students to reach out to others in order to find solutions. The facilitating teacher invites self-directed learning as they step aside to observe PBL unfold.

Teaching, instruction and coaching can be key actions to achieve the goal in a Health and physical education program today; which is to motivate all students to value a physically active lifestyle in school and beyond. In the past several teaching styles (Mosston \& Ashworth, 2008) were taught to preservice educators and to some extent this continues today in teacher training programs (Ryan, 2016). In addition to styles of teaching in Health and Physical Education, a models-based approach to instruction has been utilized (co-operative education, peer-teaching, direct instruction, personalized instruction) yet these too are falling short of the main goal in Health and Physical Education, however, regardless of the style or model it could be that critical 
teacher "... decisions about what is 'meaningful' are the province of individuals' own perceptions and interpretations" (Alexander, 2008, p.13). To address this concern PBL has a self-directed feature which is quite attractive within modern Health and Physical Education. Students select groups, take ownership and check-in frequently with the teacher who coaches (Ertmer \& Glazewski, 2015).

Teaching is more than telling students what to do and when and for how long: "Studentcentered, self-directed reflective group experiences become a pedagogy wherein pedagogy is performed with support from the "theories, beliefs, policies, and controversies that inform it" (Alexander, 2000, p. 540). The recent 2019 Ontario Ministry of Education Health and Physical Education curriculum guide includes opportunities to reflect upon and examine life itself in an authentic manner. This is not a new mode nor is it commonplace in education today. What drives the new curriculum is the understanding that students need to have the freedom to explain what they currently know, what is unknown to them and what they want or need to know. The Ontario Ministry of Education (2019) believes students will need to "practise making connections, setting goals, creating plans, making and evaluating decisions, and analysing and solving problems for which there may be no clearly defined answers" (p.28). In fact, "by assigning tasks that promote the development of critical and creative thinking skills, teachers also help students become thoughtful problem solvers and effective communicators" (Ontario Ministry of Education, 2019, p.17).

\section{Educators as coaches can encourage learning in many ways,}

for example, by giving students opportunities to apply critical thinking and problem-solving strategies and to address issues through group discussions, role play, case study analysis, and other means, they can help them develop and practise the skills they need for building healthy relationships. (Ontario Ministry of Education, 2019, p.74)

Health and well-being are "influenced not only by the absence of problems and risks but by the presence of factors that contribute to healthy growth and development" (Ontario Ministry of Education, 2019, p.5). Being an authentic inquirer is critical to PBL as "rich, open-ended questioning is the starting point for effective inquiry or for addressing a problem, it is important that teachers model this style of questioning for their students" (Ontario Ministry of Education, 2019, p.80). Students need time to reflect, process and respond to authentic problems and students need "multiple opportunities to ask, and find answers to, their own questions" (p.80).

\section{Interdisciplinary PBL in Health and Physical Education}

Students are required to successfully move through several subject areas in each grade of elementary and secondary school. With teacher guidance, coaching and encouragement,

students learn that they can apply the skills they acquire in one subject to various other contexts and subjects. For example, they can apply the problem-solving skills they use in mathematics as they learn new skills in health and physical education, and they can apply various other critical and creative thinking processes that they develop in health and physical education to their study of dance, or to question historical interpretations, or to make connections between personal actions and environmental impacts. (Ontario Ministry of Education, 2019, p.13)

Interdisciplinary PBL builds upon integrated learning which "can also be a solution to problems of fragmentation and isolated skill instruction - that is, in integrated learning, students can learn and apply skills in a meaningful context" (Ontario Ministry of Education, 2019, p.64).

The Ontario Ministry of Education (2019) curricular document suggests students learn most effectively when they have opportunities to problem solve and play an active role in their learning" (p.32). PBL shares rudimentary elements with the constructivist, self-directed learning mode which requires information that engages and stimulates students to discover new knowledge (Olsen, 2014). 


\section{PBL Skills in Health and Physical Education}

PBL necessitates the utilization of "planning skills (e.g., identifying the problem, formulating questions and ideas, gathering and organizing information; developing fitness plans, selecting strategies) use of processing skills (e.g., synthesizing information, evaluating risk and determining appropriate safety measures, revising fitness goals, detecting bias)" (Ontario Ministry of Education, 2019, p.50). Teachers are guided towards lessons that encourage the "use of critical/creative thinking processes (e.g., goal setting, decision making, problem solving; analysing movement skills, strategizing, reflecting on learning and determining steps for improvement, critiquing)" (Ontario Ministry of Education, 2019, p.50). PBL is a recursive exercise as students and teachers reflect upon what was done, and what has to be done in order to realize a desired outcome (solution) as depicted in figure three.

Figure 3

Problem Based Learning Cycle - PBL

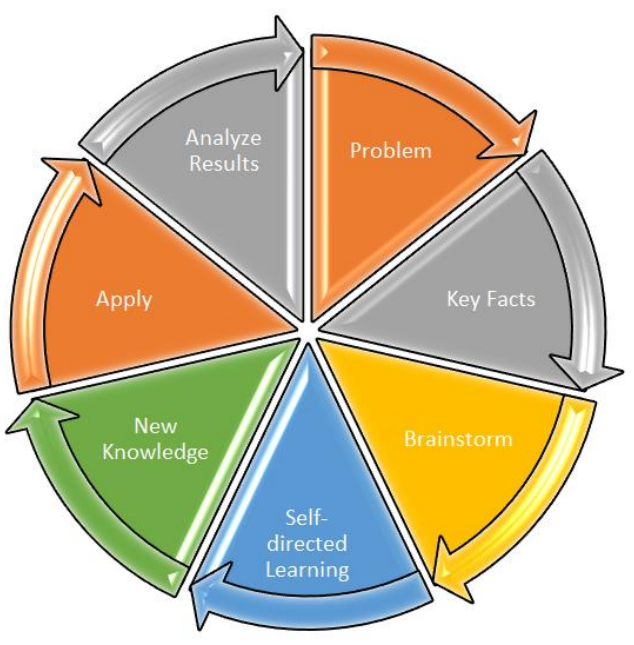

Students will use of planning skills as they prepare to teach peers, act out skits and present information perhaps within a community event such as a Health Fair. In each task students will have to identify the "problem, formulating questions and ideas, gathering and organizing information; developing fitness plans, selecting strategies . . .. Use of critical/creative thinking processes (e.g., goal setting, decision making, problem solving" (Ontario Ministry of Education, 2019 , p.52). It is through "purposeful talk, students not only learn to communicate information but also to explore and to understand ideas and concepts, identify and solve problems, organize their experience and knowledge, and express and clarify their thoughts, feelings, and opinions" (Ontario Ministry of Education, 2019, p.79)

\section{Conclusion}

The Ontario Ministry of Education (2019) curricular document lays out the expectations and in,

all strands give students a chance to engage in brainstorming, reporting, and other oral activities to identify what they know about a new topic, discuss strategies for solving a problem, present and defend ideas or debate issues, and offer critiques or feedback on work, skill demonstrations, or opinions expressed by their peers. (Ontario Ministry of Education, 2019, p.79)

For example, students "develop health literacy as they acquire the knowledge and skills they need to develop, maintain, and enjoy healthy living as well as to solve problems, make decisions, and set goals that are directly related to their personal health and mental health and well-being" (Ontario Ministry of Education, 2019, p.39). Teachers are guided to ensure that all students will be "equipped with the literacy skills necessary to be critical and creative thinkers, effective meaning makers and communicators, collaborative co-learners, and innovative problem solvers. These are 
the skills that will enable them to achieve personal, career, and societal goals" (Ontario Ministry of Education, 2019, p.78).

In all areas of the 2019 Ontario elementary health and physical education curriculum it is communicated that the pursuit of "education is one critical strategy that can help prevent problematic substance use" (Ontario Ministry of Education, 2019, p.42). The new document also suggests, "parents, guardians, educators, and society at large - all have key roles to play in educating students about substance use, misuse, and abuse" (Ontario Ministry of Education, 2019, p.42). Education about living in contemporary society requires deep learning as students "access, manage, create, and evaluate information as they think imaginatively and critically in order to solve problems and make decisions, including those related to issues of fairness, equity, and social justice" (Ontario Ministry of Education, 2019, p.78). In addition to learning about general areas of Health and wellness students are introduced to the specifics of "saving, spending, borrowing, and investing, students need to develop broader skills in problem solving, inquiry, decision making, critical thinking, and critical literacy related to financial issues, so that they can analyse and manage the risks that accompany various financial choices" (Ontario Ministry of Education, 2019, p.77). What seems to link all areas is the common thread of PBL.

\section{References}

Alexander, K. (2008). Is there a role for tactical and sport education models in school physical education? Paper presented at the First Asia-Pacific sport in education conference (pp. 1-31). Sturt Campus, Flinders University, Adelaide, AUS.

Alexander, R. J. (2000). Culture and pedagogy: International comparisons in primary education. Blackwell.

Archambault, R. D. (1964). John Dewey on education. Random House.

Barrows, H. S., \& Tamblyn, R. M. (1976). An evaluation of problem-based learning in small groups utilizing a simulated patient. Journal of Medical Education, 51(1), 52-54.

Barrows, H. S., \& Tamblyn, R. M. (1980). Problem based learning: An approach to medical education. Springer Verlag.

Barrows, H. S., \& Kelson, A. C. (1995). Problem based learning in secondary education and the problem-based learning institute. Springfield, IL.

Demirel, M., \& Dağyar, M. (2016). Effects of problem-based learning on attitude: A meta-analysis. Eurasia Journal of Mathematics, Science and Technology Education, 12(8), 2115-2137. doi:10.12973/eurasia.2016.1293a

Dewey, J. (1897). My Pedagogical Creed. School Journal, 54(3), 77-80.

Elo, S., Kääriäinen, M., Kanste, O., Polkki, T., Utriainen, K., \& Kyngas, H. (2014). Qualitative content analysis: A focus on trustworthiness. SAGE Open, 4(1), 1-10. http:// doi.org/10.1177/2158244014522633

Ertmer, P. A., \& Glazewski, K. D. (2015). Essentials for PBL implementation: Fostering collaboration, transforming roles, and scaffolding learning. In P. A. Ertmer (Ed.), Essential readings in problem-based learning (pp.89-106). Purdue University Press.

Flint, W. J. (2007). Problem-based learning: Welcome to the "real world." World Unlimited.

Faulkner, G., Goodman, J., Adlaf, E., \& Irving, H. (2007). Participation in high school physical education: Ontario, Canada, 1999-2005. Morbidity and Mortality Weekly Report, 56(3), 52-54.

Gagné, F. (2010). Motivation within the DMGT 2.0 framework. High Ability Studies, 21(2), 81-99. http:/ / doi.org/10.1080/13598139.2010.525341

Hattie, J., \& Timperley, H. (2007). The power of feedback. Review of Educational Research, 77(1), 81-112. http:/ / doi.org/10.3102/003465430298487

Hmelo-Silver, C.E. (2004). Problem-based learning: What and how do students learn? Educational Psychology Review, 16(3), 235-266. http:/ / doi.org/10.1023/b:edpr.0000034022.16470.f3

Hmelo-Silver, C. E., \& Barrows, H. S. (2015). Problem-based learning: Goals for learning and strategies for facilitating. In A. Walker, H. Leary, \& C. Hmelo-Silver (Eds.), Essential readings in problem-based learning: Exploring and extending the legacy of Howard S. Barrows (pp. 69-84). Purdue University Press.

Hubbard, G. T. (2012). Discovering constructivism: How a project-oriented activity- based media production course effectively employed constructivist teaching principles. Journal of Media Literacy Education, 4, 159166.

Hsieh, H. F., \& Shannon, S. (2018). Content Analysis. In B. Frey (Ed.), The SAGE Encyclopedia of Educational Research, Measurement, and Evaluation, (pp.393-394). Sage. 
Hsieh, H. F., \& Shannon, S. E. (2005). Three approaches to qualitative content analysis. Qualitative Health Research, 15(9), 1277- 1288.

Jerzembek, G., \& Murphy, S. (2013). A narrative review of problem-based learning with school-aged children: implementation and outcomes. Educational Review, 65(2), 206-218. http:/ / doi.org/10.1080/00131911.2012.659655

Jin, J., \& Bridges, S. M. (2014). Educational technologies in problem-based learning in health sciences education: A systematic review. Journal of Medical Internet Research, 16(12), 251. http:/ / doi.org/10.2196/jmir.3240

Johnston, L. D., Delva, J., \& O'Malley, P. M. (2007). Sports participation and physical education in American secondary schools. American Journal of Preventive Medicine, 33(4), 195-208.

Jonassen, D. H., \& Hung, W. (2008). All problems are not equal: Implications for problem-based learning. Interdisciplinary Journal of Problem-Based Learning, 2(2). https:/ / doi.org/10.7771/1541-5015.1080

Kolb, A. Y., \& Kolb, D. A. (2005). Learning styles and learning spaces: Enhancing experiential learning in Higher Education. Academy of Management Learning \& Education, 4(2),193-212.

Kolb, A. Y., \& Kolb, D. A. (2008). Experiential learning theory: A dynamic, holistic approach to management learning, education and development. Experience Based Learning Systems.

Korpi, H., Peltokallio, L., \& Piirainen, A. (2019). Problem-based learning in professional studies from the physiotherapy students' perspective. Interdisciplinary Journal of Problem-Based Learning, 13(1). https:// doi.org/10.7771/1541-5015.1732

Krippendorff, K. (2004). Content analysis: An introduction to its methodology. Sage.

Lattuca, L. (2006). The constructivist pedagogy we're looking for. Journalism \& Mass Communication Educator, 60, 354-358. http:/ / doi.org/10.1177/107769580506000404

Lu, J., \& Chan, L. K. (2015). Differ in socio-cognitive processes? Some comparisons between paper and video triggered PBL. Interdisciplinary Journal of Problem-Based Learning, 9(2). https://doi.org/10.7771/15415015.1495

McCaughan, K. (2015). Theoretical anchors for Barrows' PBL tutor guidelines. In A.Walker, H. Leary, \& C. Hmelo-Silver (Eds.), Essential readings in problem- based learning: Exploring and extending the legacy of Howard S. Barrows (pp. 57-68). Purdue University Press.

Mosston, M., \& Ashworth, S. (2008). Teaching physical education: First online edition. Spectrum Institute for Teaching and Learning. https:/ / spectrumofteachingstyles.org/index.php?id=16

Murphy, P. (2008). Defining pedagogy. In K. Hall, P. Murphy \& J. Soler (Eds.), Pedagogy and practice: culture and identities (pp. 28-39). Sage.

Norman, G. R., \& Schmidt, H. G. (1992). The psychological basis of problem-based learning: A review of the evidence. Academic Medicine, 67(9), 557-565.

Olsen, D. (2014). Jerome Bruner: The cognitive revolution in educational theory. Bloomsbury.

Ontario Ministry of Education. (2019). The Ontario curriculum, grades 1-8: Health and Physical Education. Ontario: Queen's Printer for Ontario.

Pagander, L., \& Read, J. (2014). Is problem-based learning (PBL) an effective teaching method? A study based on existing research. Linköpings universitet. http://www.divaportal.org/smash/get/diva2:726932/FULLTEXT01.pdf

Piaget, J. (1990). The child's concept of the world. Littlefield Adams.

Poikela, E., \& Poikela, S. (2006). Problem-based curricula: Theory, development and design. In E. Poikela \& A. R. Nummenmaa (Eds.),Understanding problem-based learning (pp. 71-90). Tampere University Press.

Rasi, P. M., \& Poikela, S. (2016). A review of video triggers and video production in higher education and continuing education PBL settings. Interdisciplinary Journal of Problem-Based Learning, 10(1). https:/ / doi.org/10.7771/1541-5015.1609

Ryan, T. G. (2016). The pre-service educator as action researcher and leader. Action Researcher in Education, 7, $1-13$.

Savery, J. (2006). Overview of problem-based learning: Definitions and distinctions. Interdisciplinary Journal of Problem-Based Learning, 1(1), 9-20. http:/ / dx.doi.org/10.7771/1541-5015.1002

Savery, J. R., \& Duffy, T. M. (1995). Problem based learning: An instructional model and its constructivist framework. Educational Technology, 35(5), 31-38.

Scholkmann, A., \& Roters, B. (2009). Measuring the effects of problem-based learning - progress in the development of a scale to rate the acquisition of professional knowledge through PBL. ECER 2009, Theory and Evidence in European Educational Research. Technische Universitat of Dortmund, Austria.

Schon, D. (1983). The reflective practitioner. Maurice Temple.

Schreier, M. (2012). Qualitative content analysis in practice. Sage. 
Shernoff, D. J., Csikszentmihalyi, M., Schneider, B., \& Shernoff, E. S. (2003). Student engagement in high school classrooms from the perspective of flow theory. School Psychology Quarterly, 18(2), 158-176. https:/ / doi.org/10.1521/scpq.18.2.158.21860

Siminica, M., \& Traistaru, A. (2013). Self-directed learning in economic education. International Journal of Education and Research, 1(12), 1-14.

Simons, K. D., \& Ertmer, P.A. (2005). Scaffolding disciplined inquiry in problem-based environments. International Journal of Learning, 12(6), 297-305. https:/ / doi.org/10.18848/1447-9494/CGP/v12i06/47900

Stemler, S. (2001). An introduction to content analysis. ERIC Digest, ED458218.

Tarmizi, A. T., \& Bayat, S. (2012). A collaborative problem-based learning in mathematics: A cognitive load perspective. Procedia Social and Behavioral Sciences, 32(1), 344-350.

Tennyson, R. D. (2010). Historical reflection on learning theories and instruction design. Contemporary Educational Technology, 1(1), 1-16.

Torp, L., \& Sage, S. (2002). Problems as possibilities: PBL for K-16 education. http://pbln.imsa.edu/resources/PBL_Matters.pdf

Vygotsky, L. S. (1934). Thought and language (E. Hanfmann \& G. Vakar, Trans.). MIT Press, Massachusetts Institute of Technology.

Wilson, B. G. (2010). Constructivism in practical and historical context. In B. Reiser \& J. Dempsey (Eds.), Current trends in instructional design and technology (pp.1-10). Pearson Prentice Hall.

Yew, E. H. J., \& Goh, K. (2016). Problem-based learning: an overview of its process and impact on learning. Health Professions Education, 2(2), 75-79. 